\title{
RANCANG BANGUN SISTEM KEAMANAN SEPEDA MOTOR VIA PONSEL
}

\author{
Fahmi Zikri, Salahuddin, Misbahul Jannah \\ Jurusan Teknik Elektro, Fakultas Teknik Universitas Malikussaleh \\ Kampus Bukit indah, Jalan Batam No. 16 Kecamatan Blangpulo Lhokseumawe \\ E-mail : salahuddin_upm@yahoo.co.id
}

\begin{abstract}
Abstrak - Perkembangan teknologi, handphone merupakan salah satu teknologi yang sangat digandrungi masyarakat. Ada dua hal penting aplikasi yang ada di ponsel yang dapat di manfaatkan yaitu telepon (percakapan) dan SMS (Short Message Service). Dengan memanfaatkan fasilitas ini dan menambahkan sedikit rangkaian elektronik sederhana, maka fungsi ponsel tidak hanya untuk sarana alat komunikasi via suara ataupun SMS (Short Message Service) tetapi juga dapat dimanfaatkan sebagai alat pengaman pada sepeda motor. Hasil penelitian rancang bangun sistem keamanan sepeda motor via ponsel dapat disimpulkan bahwa sitem akan memanggil (menelpon) pemilik sepeda motor apabila sepeda motor di hidupkan secara paksa. Sistem akan mematikan mesin sepeda motor dan menghidupkan alarm jika handphone sistem mendapat panggilan dari handphone pemilik kendaraan dan sepeda motor yang telah mati secara otomatis tidak dapat dihidupkan dengan kunci kontak sebelum menekan tombol reset pada modul. Pada pengukuran rangkaian pengirim sinyal ( $T x)$, tegangan Vin 12,8 Volt dari kelistrikan mesin yang melewati transistor, basis pada transistor 11,56 Volt merupakan pemicu bagi relay 1 maka kontaktor relay 1 yang akan mengontakkan tombol keypad pada handphone. Dari hasil pengukuran tidak terlalu jauh selisih dengan perhitungan, dimana pada hasil pengukuran adalah sebesar $11,78 \mathrm{~V}$ dan hasil perhitungan sebesar 11,56 V. Dari hasil pengukuran dengan hasil perhitungan terdapat selisih sebesar 0,22 Volt. Dari hasil pengujian sistem ini akan memberikan informasi saat sepeda motor di aktifkan dan akan mematikan sepeda motor dalam waktu 18 detik dengan jarak kurang lebih 25 meter.
\end{abstract}

Keywords - Handphone, Short Message Service, sepeda motor, alarm.

\section{PENDAHULUAN}

Semakin kerasnya kehidupan menyebabkan banyak orang menjadi gelap mata. Mereka menghalalkan segala cara untuk memenuhi kebutuhan hidup mereka demi mempertahankan kelangsungan hidupnya, seperti merampok, korupsi, mencuri, dan tindakan-tindakan kriminal lainnya. Salah satu tindakan kriminal yang baru maraknya di era sekarang adalah tindakan kriminal pencurian sepeda motor.Tidak hanya di malam hari dan di tempat yang sepi saja, di siang hari dan di keramaian pun para pencuri dapat melakukan aksi dengan mudahnya. Maka dibutuhkan kewaspadaan yang ekstra untuk menjaga sepeda motor kita.
Dengan meningkatnya tindak kriminalitas, khususnya pencurian kendaraan bermotor roda dua sekarang ini, bukanlah hal yang mengherankan apabila semakin hari manusia menginginkan suatu sistem keamanan sepeda motor yang modern.Solusi yang biasa dilakukan oleh pemilik kendaraan bermotor hanya dengan memakai kunci (gembok), tetapi pemilik sering lupa memasang kunci (gembok). Apalagi pencuri kendaraan bermotor dapat membuat kunci-kunci duplikat sehingga pencuri kendaraan bermotor bisa dengan santai melakukan aksinya dengan tidak mengundang kecurigaan .

Di sisi lain, seiring dengan perkembangan teknologi, handphone merupakan salah satu teknologi yang sangat digandrungi masyarakat. Dengan uang ratusan ribu saja sudah dapat digenggam ponsel kamera lengkap dengan blutooth dan aplikasi.Ada dua hal penting aplikasi yang ada di ponsel yang dapat di manfaatkan yaitu telepon (percakapan) dan SMS (Short Message Service). Dengan memanfaatkan fasilitas ini dan menambahkan sedikit rangkaian elektronik sederhana, maka fungsi ponsel tidak hanya untuk sarana alat komunikasi via suara ataupun SMS (Short Message Service) tetapi juga dapat dimanfaatkan sebagai alat pengaman pada sepeda motor yang nantinya dapat juga dikembangkan pada mobil.

Di era dimana saat curanmor ditakuti tetapi ponsel digandrungi. Inilah saatnya memanfaatkan teknologi dari ponsel yang telah dimiliki banyak pihak sebagai sistem keamanan serta kepraktisan untuk hidup lebih baik.

\section{DASAR TEORI}

\section{Telepon Seluler (Handphone)}

Komunikasi melalui penggunaan ponsel (telepon seluler) hampir sama saja dengan komunikasi melalui penggunaan telepon rumah biasa. Dalam telepon seluler yang menghubungkannya adalah gelombang - gelombang radio yang dilewatkan dari pesawat ke BTS (Base Transceveir Station - Setasiun induk kirim terima) dan MSC (Mobile Switching Center - Pusat senteral telepon bergerak) yang bertebaran disepanjang jalur hubungan, kemudian siteruskan ke pesawat yang dipanggil.

Yang mana telepon seluler merupakan perangkat telekomunikasi elektronik yang mempunyai kemampuan dasar yang sama dengan telepon konvensional saluran tetap, namun dapat dibawa ke mana-mana (portable, mobile) dan 
tidak perlu disambungkan dengan jaringan telepon menggunakan kabel (nirkabel, wireless). Saat ini Indonesia mempunyai dua jaringan telepon nirkabel yaitu sistem GSM (Global System for Mobile Telecommunications), sistem CDMA (Code Division Multiple Access).

\section{GSM (Global System for Mobile Communication)}

GSM merupakan sebuah teknologi komunikasi selular yang bersifat digital, karena GSM memakai teknologi digital dan metode transmisi time Division Multiple Access. Voice atau suara diencod secara digital melalui sebuahEncoder unik, yang mana mengemulasi karakteristik dari pembicaraan manusia.Metode transmisi ini membuat rasio data/informasi sangat efisien.

Teknologi GSM banyak diterapkan pada mobile communication, khususnya hanphone. Teknologi ini emmanfaatkan gelombang mikro dan pengirin sinyal yang dibagi berdasarkan waktu, sehingga sinya informasi yang dikirim akan sampai pada tujuan. GSM dijadikan standar global untuk komunikasi selular sekaligus sebagai seluler yang paling banyak digunakan orang diseluruh dunia.

Suatu hal yang perlu diketahui bahwa GSM hanya berfungsi bila dioperasikan dalam area pelayanan BTS( Abse Tranceuver Station-stasiun induk pengirim dan penerima ) yang membawahi sejumlah pelanggan. Bila ia berada diluar wilayah cakup BTS, telepon seluler ini tiadak adapat bekerja, sehingga dilayar akan bertulis no service. Arna itu hidup matinya amat ditentukan oleh kedekatannya dengan BTS dimaksud.Telepon seluler GSM di Indonesia bekerja pada frekuensi 890-960 Mhz.Lebar band(bandwitch)nya $25 \mathrm{Mhz}$, sampai dengan frekuensi $200 \mathrm{Mhz}$ diperoleh 124 slot frekuensi. Semua selot frekuensi itulah yang dibagi-bagi kepada para operator GSM di Indonesia (PT. Satelindo,PT Telkomsel,PT Excelcomindo).

\section{Light Dependent Resistor (LDR)}

Resistor peka cahaya Light Dependent Resistor (LDR) memanfaatkan bahan semikonduktor yang karakteristik listriknya berubah-ubah sesuai dengan cahaya yang diterima. Bahan yang digunakan adalah Kadmium Sulfida (CdS) dan Kadmium Selenida (CdSe). Bahan-bahan ini paling sensitive terhadap cahaya dalam spectrum tampak, dengan puncaknya sekitar 0,6 $\mu \mathrm{m}$ untuk CdS dan 0,75 $\mu \mathrm{m}$ untuk CdSe. Sebuah LDR CdS yang typical memiliki resistansi sekitar $1 \mathrm{M} \Omega$ dalam kondisi gelap gulita dan kurang dari $1 \mathrm{~K} \Omega$ ketika ditempatkan dibawah sumber cahaya terang (Malvino, 1996).

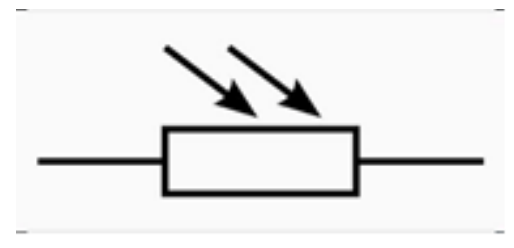

Gambar 2.1 Like Dependent Resistor

\section{Regulator LM 7805}

IC regulator disini mempunyai fungsi untuk menstabilkan tegangan DC.IC regulator yang digunakan pada system ini adalah LM7805.LM7805 memiliki tegangan keluaran tertentu tergantung dari jenis IC tersebut dan untuk LM7805 menghasilkan tegangan keluaran +5VDC.

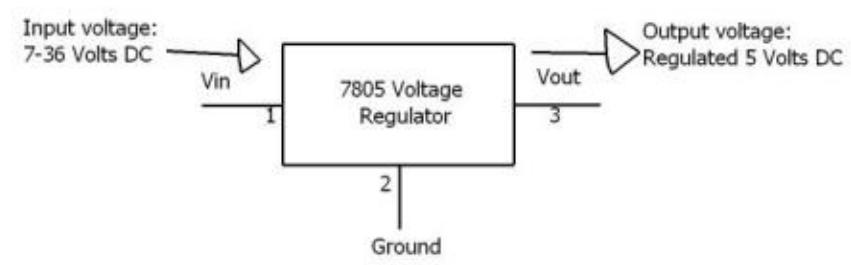

\section{Gambar 2.2 Skematik IC Adjustable Regulator LM7805}

Voltage Regulator 5V, sangat diperlukan untuk membuat power supply rangkaian. Spesifikasi :

- Kemasan TO-220

- Output : 5V

- $\quad$ Arus : $1.5 \mathrm{~A} \mathrm{Max}$

\section{LED ( Light-Emitting Diode )}

LED ( Light-Emitting Diode) suatu semikonduktor yang memancarkan cahaya monokromatik yang tidak koheren ketika diberi tegangan maju. Gejala ini termasuk bentuk elektroluminesensi. Warna yang dihasilkan bergantung pada bahan semikonduktor yang dipakai, dan bias juga ultraviolet dekat atau inframerah dekat.

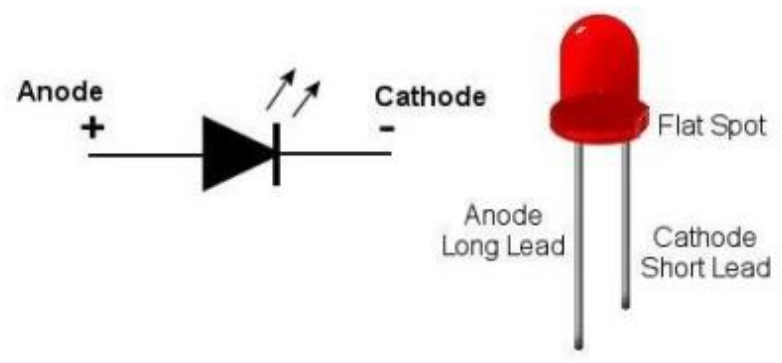

Gambar 2.3 Komponen LED ( Light-Emitting Diode)

LED adalah sejenis diode semikonduktor istimewa.Seperti sebuah diode 'normal, LED terdiri dari sebuah chip bahan semikonduktor yang diisi penuh, atau didop, dengan ketidakmurnian untuk menciptakan sebuah struktur yang disebut p-n junction.Pembawa-muatan elektron dan lubang mengalir ke junction dari elektroda dengan voltase berbeda.Ketika elektron bertemu dengan lubang, dia jatuh ke tingkat energi yang lebih rendah, dan melepas enenrgi dalam bentuk photon.Panjang gelombang dari cahaya yang dipancarkan, dan oleh karena itu warnannya, tergantung dari selisih pita energi dari bahan yang membentuk p-n junction.Sebuah dioda normal, biasanya terbuat darai silikon atau germanium, memancarkan cahaya tampak inframerah dekat, tetapi bahan 
yang digunakan untuk sebuah LED memiliki selisih pita energi antara cahaya inframerah dekat, tampak dan ultraungu dekat.

LED terbuat dari berbagi material setengah penghantar campuran seperti misalnya galium arsenida fosfida (GaAsP), galium fosfida (Gap) dan galium alumunium arsenida (GaAsp). Karakteristik yaitu kalu diberi panjaran maju, pertemuannya mengeluarkan cahaya dan warna cahaya tergantung pada jenis dan kadar material pertemuan. Ketandasan cahaya bebanding lurus dengan arus maju yang mengalir. Dalam kondisi menghantar, tegangan maju pada LED merah adalah 1,6 sampai 2,2 volt, LED kuning 2,4 volt, LED hijau 2,7 volt. Sedangkan tegangan terbaik maksimum yang diperbolehkan pada LED merah adalah 3,0 volt, LED kuning 5 volt, LED hijau 5 volt.

Tak seperti lampu pijar dan neon, LED mempunyai kecenderungan polarisasi. Chip LED mempunyai kutup positif dan negatif (p-n) dan hanya akan menyala bila diberikan arus maju. Ini dikarenakan LED terbuat dari bahan semikonduktor yang hanya akan mengizinkan arus listrik mengalir ke satu arah dan tidak ke arah sebaliknya. Bila LED diberikan arus terbalik, hanya akan ada sedikit arus yang melewati chip LED tidak akan mengeluarkan emisi cahaya. Chip LED pada umumnya mempunyai tegangan rusak yang relatif rendah. Bila diberikan tegangan beberapa volt ke arah terbalik, biasanya sifat isolator searah LED akan jebol menyebabkan arus dapat mengalur ke arah sebaliknya (Bishop, 2004).

\section{Dioda Infra Merah}

Biasanya sebuah LED adalah sebuah dioda P-N, yang biasanya dibuat dari bahan semikonduktor seperti Almunium-Galium-Arsinede (AlGaAs) atau GaliumArsinede-Phospide (GaAsP). Dioda Infra merah memancarkan cahaya oleh emisi spontan dimana cahaya dipancarkan sebagai hasil dari pengkombinasian dari elektron-elektron dan hole-hole.

Untuk memperoleh jarak yang cukup jauh, Dioda infra merah memerlukan sinyal dengan frekuensi 30 hingga 50 $\mathrm{kHz}$. Berbeda dengan Dioda LED yang hanya memerlukan level tegangan DC saja untuk mengaktifkan LED, Dioda Infra merah memerlukan sinyal AC dengan frekwensi 30 hingga $50 \mathrm{kHz}$ untuk mengaktifkannya. Cahaya infra merah tersebut tidak dapat ditangkap oleh mata manusia, sehingga diperlukan phototransistor untuk mendeteksinya.

Transmisi data dilakukan dengan menggunakan prinsip aktif dan non aktifnya LED infra merah sebagai kondisi logika 0 dan logika 1 . Seperti telah dijelaskan sebelumnya bahwa untuk mengaktifkan LED Infra merah diperlukan frekuensi sebesar 30 hingga $40 \mathrm{kHz}$, maka dalam hal ini logika 0 berarti sinyal berfrekwensi $30 \mathrm{KHz}$ mengalir ke LED Infra merah dan logika 1 berarti tidak ada sinyal yang mengalir ke LED Infra merah (Bishop, 2004).

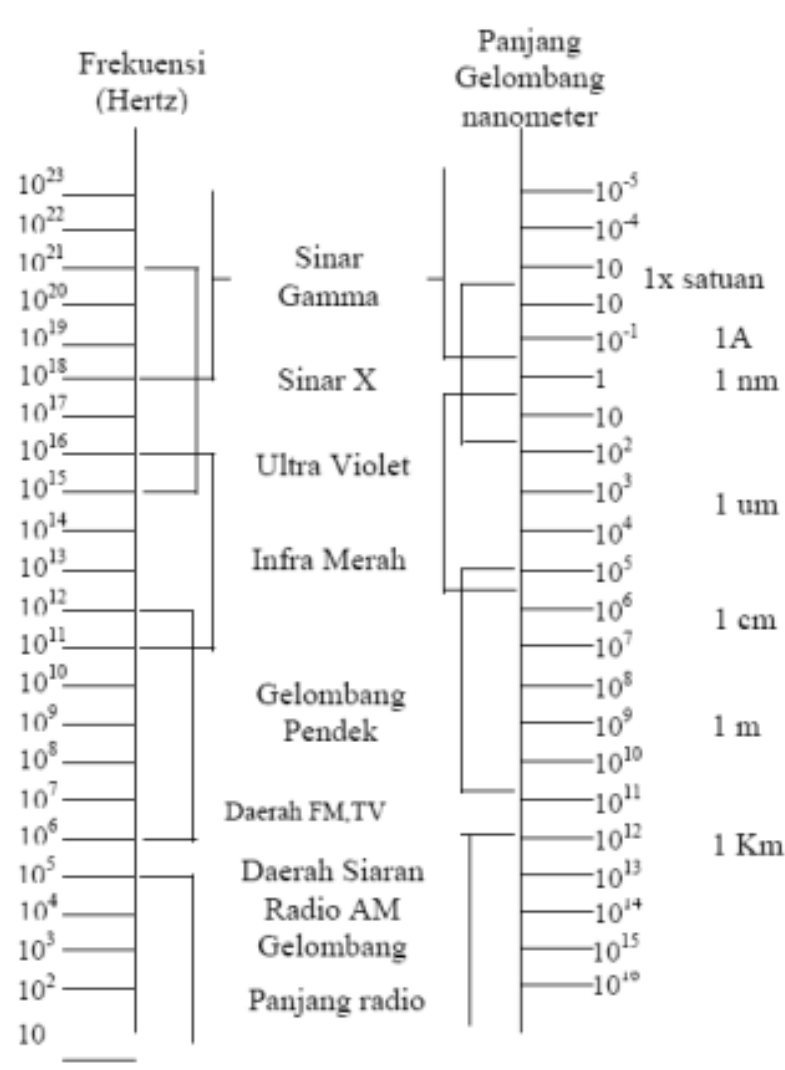

Gambar 2.4 Spektrum Gelombang Elektromagnetik

Spektrum sinar infra merah terdapat pada spektrum gelombang elekromagnetik. Gambar 2.4 menunjukkan spektrum gelombang infra merah yang terdapat pada salah satu diantara spektrum gelombang elektromagnetik.

Ciri-ciri gelombang infra merah meliputi :

a. Sinar infra merah meliputi daerah frekuensi antara 1011 sampai 1014 Hertz dan mempunyai daerah panjang gelombang 10-4 sampai $10-1 \mathrm{~cm}$.

b. Gelombang infra merah ini dihasilkan oleh elektron-elektron dalam molekul yang bergetar karena benda yang dipanaskan.

c. Sinar Infra Merah dapat menembus kabut dan awan tebal.

Gelombang infra merah tidak dapat diamati secara langsung karena spektrum gelombang infra merah diatas gelombang cahaya yang tampak oleh panca indera kita. Radiasi sinar infra merah dapat dihasilkan oleh getarangetaran atom-atom pada suatu molekul. Getaran atom pada suatu molekul dapat memancarkan gelombang elektromagnetik pada frekuensi yang khas pada infra merah sehingga spekstroskopi infra merah dapat merupakan salah satu alat penting untuk mempelajari struktur molekul.

\section{Relay}

Relay adalah sebuah saklar yang dikendalikan oleh arus. Relay memiliki sebuah kumparan tegangan-rendah yang dililitkan pada sebuah inti. Terdapat sebuah armatur besi yang akan tertarik menuju inti apabila arus mengalir 
melewati kumparan. Armatur ini terpasang pada sebuah tuas berpegas. Ketika armatur tertarik menuju ini, kontak jalur bersama akan berubah posisinya dari kontak normal-tertutup ke kontak normal-terbuka.

Kontak Poin (Contact Point) Relay terdiri dari 2 jenis yaitu:

- Normally Close (NC) yaitu kondisi awal sebelum diaktifkan akan selalu berada di posisi CLOSE (tertutup)

- Normally Open (NO) yaitu kondisi awal sebelum diaktifkan akan selalu berada di posisi OPEN (terbuka)

Jika input relay diberi bias arus maka pada kumparan akan terdapat induksi magnetic yang nantinya akan menarik pegas kontak untuk merubah posisi awalnya menjadi terhubung ke bagian yang diinginkan. Setelah arus terhenti, maka tidak ada induksi sehingga kontak akan kembali ke posisi semula. Berikut ini adalah simbol relay.

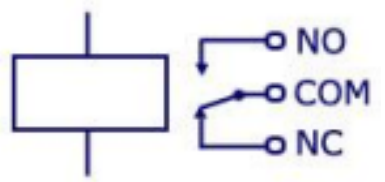

\section{Gambar 2.5 Simbol Relay}

Relay diaktifkan dengan beberapa komponen tambahan yang akan menghubungkan jalur positive maupun jalur negative yang mampu menerima sinyal logika. Komponen tambahan yang digunakan adalah transistor PNP untuk aktif pada sinyal logika " 0 " dan NPN untuk aktif pada logika " 1 ", menggunakan resistor pada input dan menggunakan dioda sebagai peredam tegangan balik pada relay sehingga transistor tidak mudah rusak. Rumus perhitungan lilitan pada relay adalah sebagai berikut.

$$
N_{\mathrm{n}}=\frac{L}{d}
$$

Dimana:

$$
\begin{array}{ll}
\mathrm{N}_{\mathrm{n}} & =\text { Jumlah Lilitan } \\
\mathrm{L} & =\text { Panjang induktor } \\
\mathrm{D} & =\text { Diameter kawat }
\end{array}
$$

Jika makin besar, maka $\mathrm{N}_{n}$ akan semakin kecil, sebaliknya jika nilai $d$ lebih kecil, maka $\mathrm{N}_{n}$ akan semakin besar sehingga dapat merusak transistor, oleh karena itu dgunakan sebuah dioda yang akan membias reserve, sehingga akan tercipta resistansi yang sangat besar dan hampir menuju tak terhingga pada dioda yang mampu meredam tegangan pada lilitan relay.

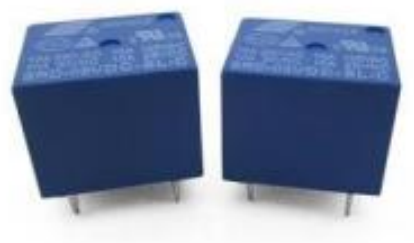

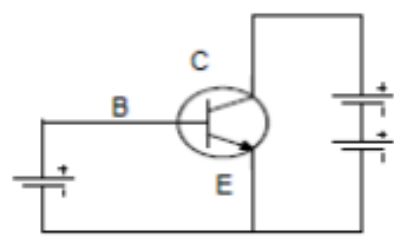

(a)

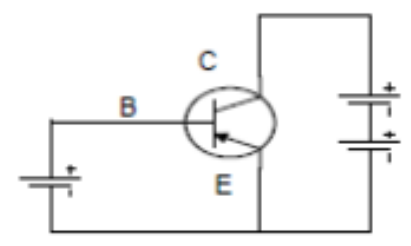

( b )
Gambar 2.7 Dasar Polaritas Transistor

Transistor adalah suatu komponen yang dapat memperbesar level sinyal keluaran sampai beberapa kali sinyal masukan. Sinyal masukan disini dapat berupa sinyal AC ataupun DC. Prinsip dasar transistor sebagai penguat adalah arus kecil pada basis mengontrol arus yang lebih besar dari kolektor melewati transistor. Transistor berfungsi sebagai penguat ketika arus basis berubah. Perubahan kecil arus basis mengontrol perubahan besar pada arus yang mengalir dari kolektor ke emitter. Pada saat ini transistor berfungsi sebagai penguat.

Dan dalam pemakiannya transistor juga bisa berfungsi sebagai saklar dengan memanfaatkan daerah penjenuhan (saturasi) dan daerah penyumbatan (cut-off). Pada daerah penjenuhan nilai resistansi penyambungan kolektor emitter secara ideal sama dengan nol atau kolektor terhubung langsung (short). Ini menyebabkan tegangan kolektor emitter $\mathrm{V} c e=0$ pada keadaan ideal. Dan pada daerah cut off, nilai resistansi persambungan kolektor emitter secara ideal sama dengan tak terhingga atau terminal kolektor dan emitter terbuka yang menyebabkan tegangan Vce sama dengan tegangan sumber Vcc( Malvino, 1996 : 83) 


\section{METODOLOGI}

Metode pelaksanaan yang digunakan dalam pelaksanaan sistem keamanan Sepeda Motor ini adalah sebagai berikut

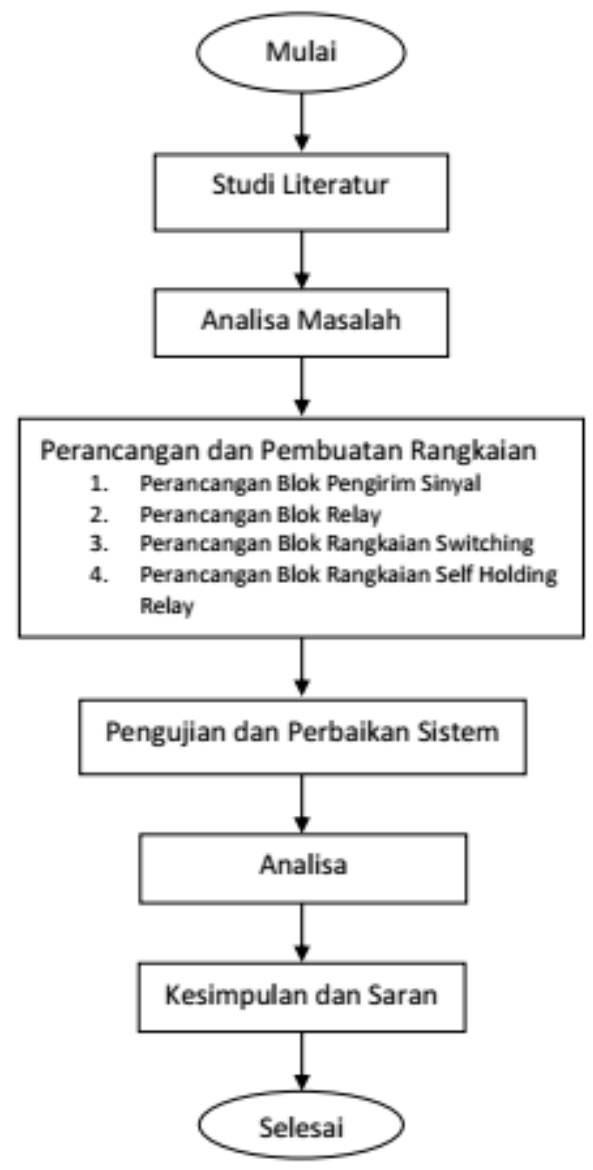

Gambar 3.1. Flowchart Penelitian

Perancangan dan Pembuatan Rangkaian

$\begin{array}{lrr}\text { Membuat perancangan } & \text { kemudian } \\ \text { engimplementasikannya terhadap alat berdasarkan }\end{array}$ parameter-parameter yang diinginkan dan merealisasikannya. Perancangan tersebut dibagi menjadi beberapa bagian yaitu sebagai berikut.

Blok diagram perancangan tersebut memiliki spesifikasi sebagai berikut:

1. Catu daya (power supply)

2. Charger hanphone

3. Pengirim sinyal

4. Rangkaian Switching

5. Rangkaian Self Holding Relay

6. Rangkaian Relay

\section{Blok Diagram Rangkaian}

Secara keseluruhan dalam perancangan dan pembuatan alat pengaman sepeda motor terlebih dahulu diperhatikan diagram blok untuk memberi penjelasan dari komponen yang akan digunakan. Diagram blok seperti yang ditunjukkan pada gambar 3.2.

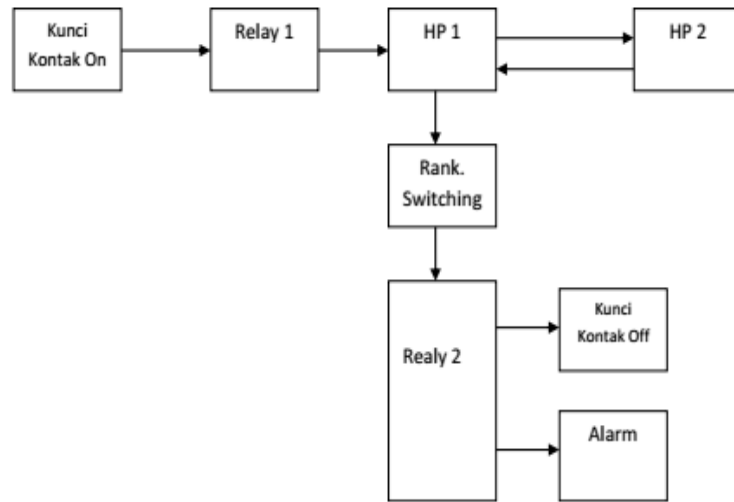

Gambar 3.2Diagram Blok Sistem Pengaman

Keterangan :

- Kunci kontak sepeda motor

- Relay 1 : Untuk menekan tombol keyped pada handphone

- HP 1 : HP yang ada pada modul

- Relay 2 : Untuk mematikan kunci kontak dan menghidupkan alaram

- HP 2 : HP yang ada pada pemilik sepeda motor

\section{Prinsip Kerja}

1. Pada saat motor dimatikan dengan cara memutar tuas kunci (pada posisi off), dan rangkaian diaktifkan dengan cara meng-ON kan swicth maka secara otomatis rangkaian akan dengan mendapatkan arus dari aki motor.

2. Pemilik motor dapat meninggalkan sepeda motornya dengan catatan bahwa pulsa di dalam Handphone pada sepeda motor cukup untuk melakukan panggilan dan SMS. Selain itu handphone pada pemilik sepeda motor juga harus selalu dalam kondisi ON dan ada pulsa di dalamnya.

3. Apabila pencuri sukses membobol kunci (mesin berhasil menyala), maka ponsel tersembunyi akan melakukan panggilan cepat ke nomor pemilik sepeda motor (telah disetting nomornya), beberapa saat setelah kunci on / mesin menyala.

4. Pemilik sepeda motor akan menerima panggilan dari handphone yang ada pada sepeda motor dan pemilik akan mengetahui bahwa sepeda motornya telah dibobol. Maka pemilik sepeda motor akan melakukan panggilan balik ke nomor handphone yang ada pada sepeda motor.

5. Seiring dengan adanya panggilan (telepon masuk) dari pemilik sepeda motor maka sistem akan bekerja dengan memutuskan aliran arus dari CDI ke mesin sehingga sepeda motor akan mati total dan alarm akan menyala.

6. Sistem akan OFF jika pemilik sepeda motor sendiri yang akan mematikan sistem yang ada pada sepeda motor. 


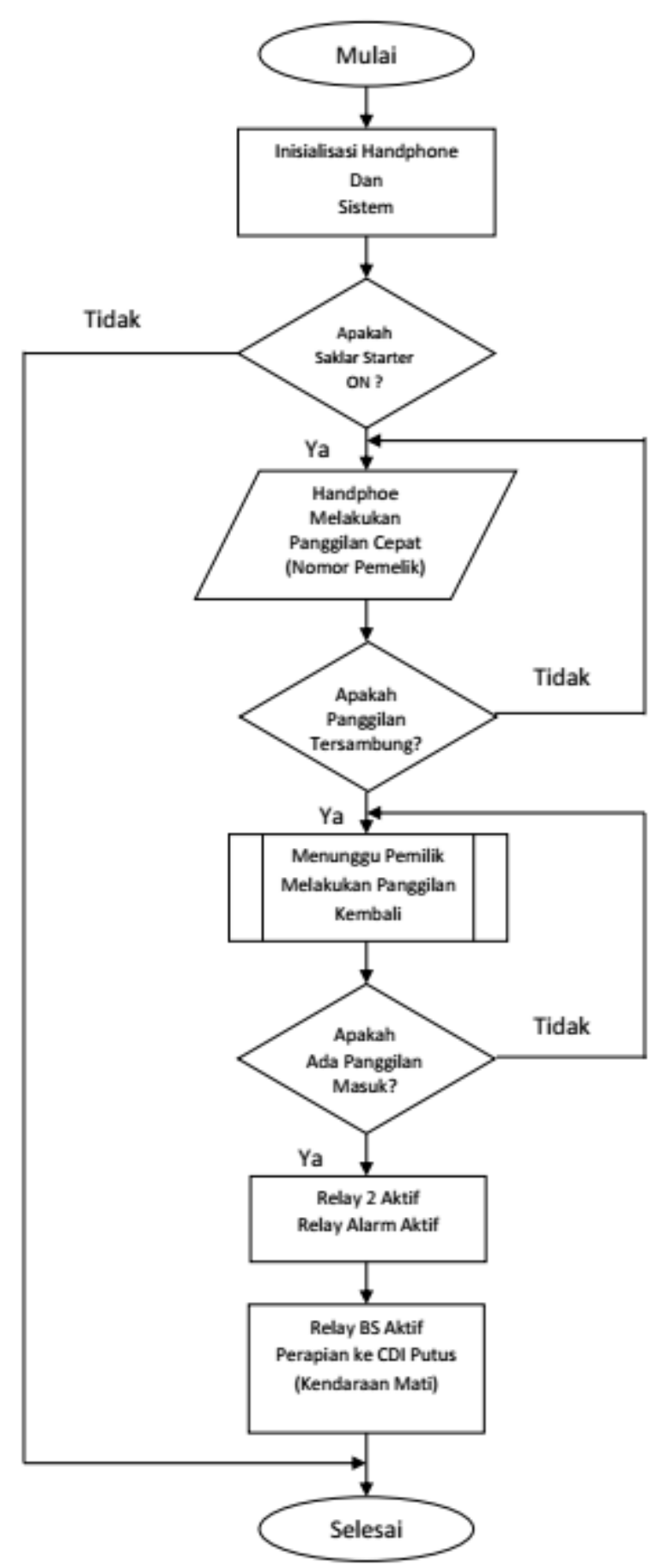

Gambar 3.3 Flowchart Sistem Pengaman Kendaraan Bermotor

\section{Rangkaian modul}

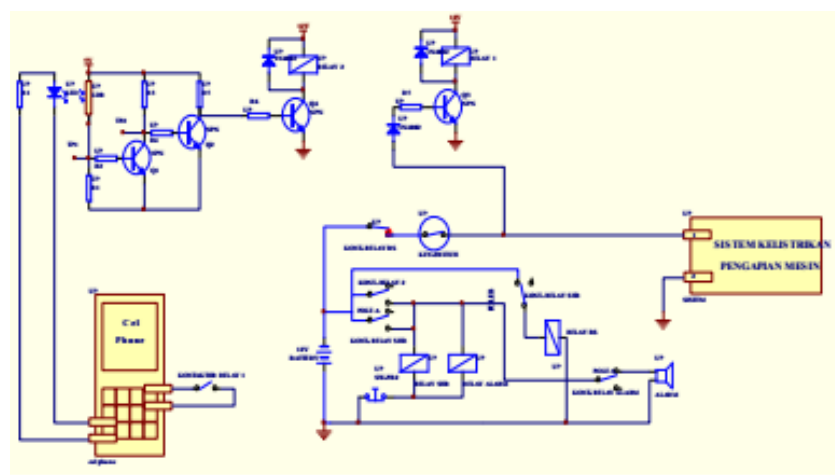

Gambar 3.4 Rangkaian Modul

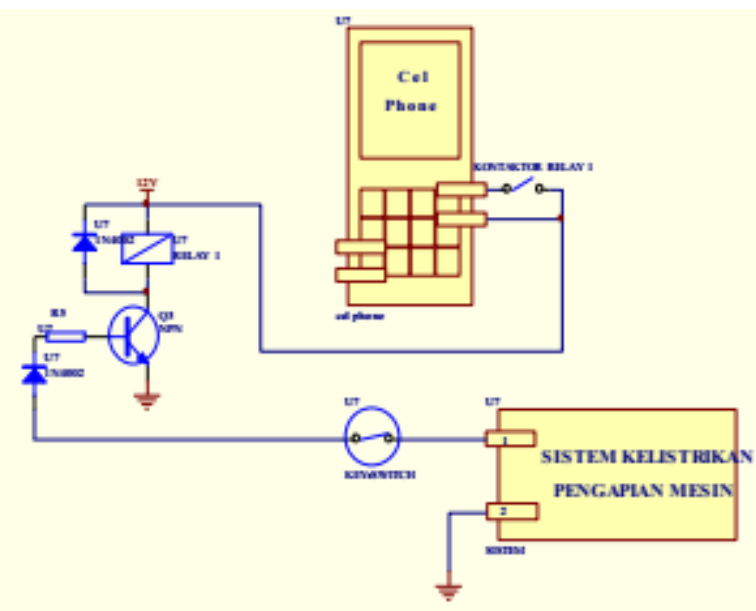

Gambar 3.5 Rangkaian pengirim sinyal (TX)

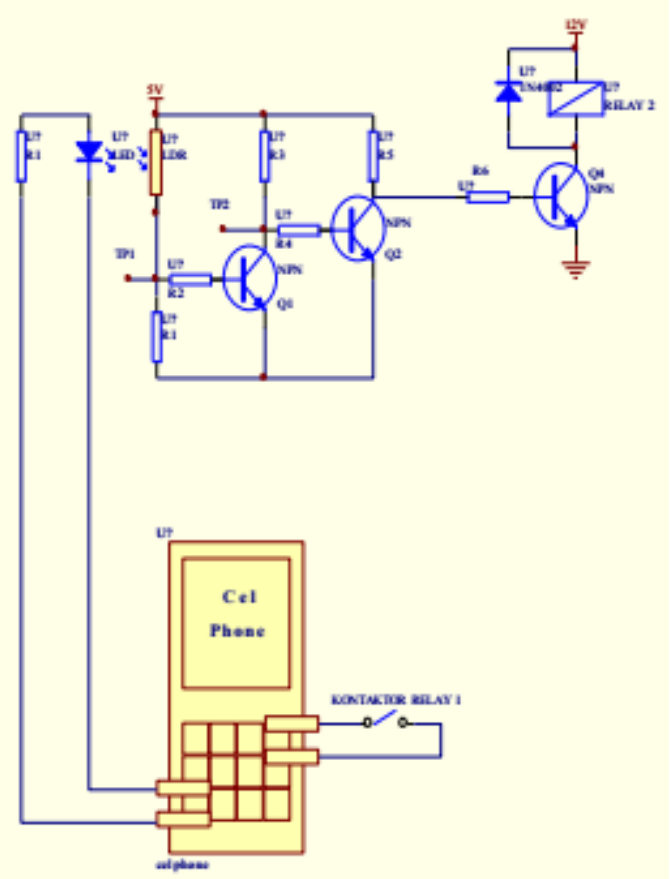

Gambar 3.6 Rangkaian switching 


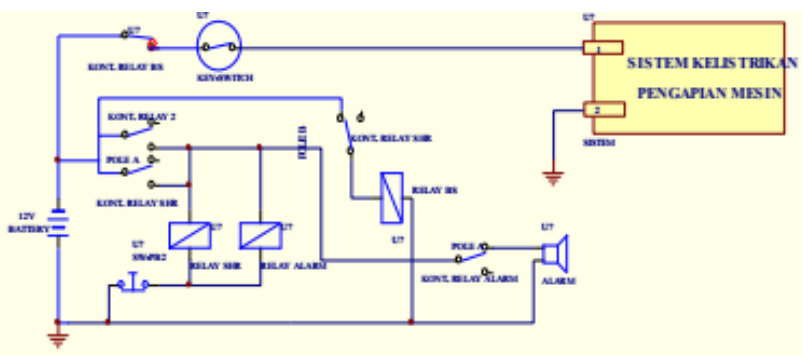

Gambar 3.7 Rangkaian Self Holding Relay

\section{ANALISA DAN PEMBAHASAN}

Untuk mengetahui tegangan kerja dari suatu rangkaian dalam keadaan bekerja normal, apabila terjadi kesalahan kesalahan yang sangat mempengaruhi pengoperasian rangkaian dapat dilakukan pemeriksaan ulang terhadap tegangan kerja, menurut test point (TP) yang ditentukan seperti yang terdpat dalam gambar rangkaian dibawah ini.

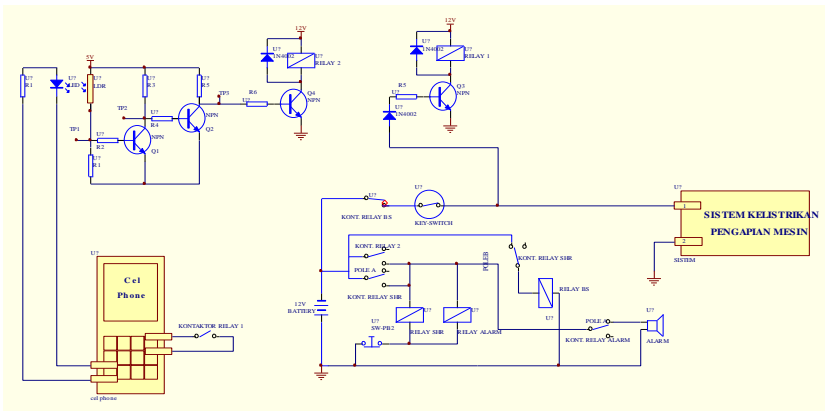

Gambar 4.1 Titik Pengukuran Keseluruhan

\section{Hasil Pengujian}

Pengukuran catu daya dilakukan untuk mengetahui apakah tegangan yang dihasilkan sesuai dengan tegangan yang dibutukan. Dibawah ini merupakan rangkaian dan tabel hasil pengukuran catu daya :

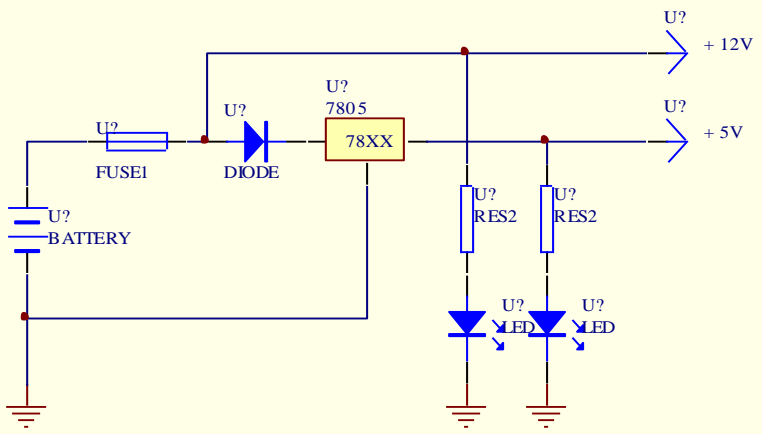

Gambar 4.2 Rangkaian power supply

\section{Hasil pengukuran power supply}

Tabel 4.1 Pengukuran Power Supply

\begin{tabular}{|c|l|c|}
\hline No & \multicolumn{1}{|c|}{ Komponen } & Vin \\
\hline 1 & Baterai Kendaraan & 12,8 VDC \\
\hline 2 & LM7805 & 5,02 VDC \\
\hline 3 & Rangkaian Switcihing & 5,02 VDC \\
\hline 4 & Relay & 12,8 VDC \\
\hline 5 & Baterai Hp & 4,41 VDC \\
\hline 6 & Alarm & 12,8 VDC \\
\hline
\end{tabular}

\section{Analisa}

Pada rangkaian pengirim sinyal (Tx) tegangan inputnya langsung diambil dari tegangan bateray hanphone 4,41 Volt, sedangkan pada rangkaian swiching komponen LDR Vin nya sebesar 5,02 Volt melalui IC Regulator 7805 dan pada relay juga alarm Vin nya sebesar 12,8 Volt. Data hasil pengukuran dapat dilihat pada Tabel 4.1.

\section{Pengujian Dan Pengukuran Rangkaian Pengirim Sinyal} (TX)

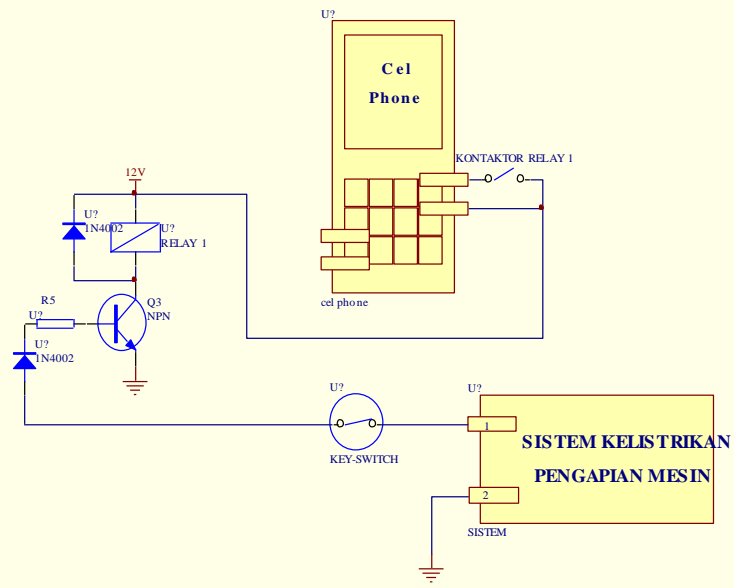

Gambar 4.3 Rangkaian Pengirim Sinyal

\section{Hasil Pengukuran}

Tabel 4.2 Pengukuran Rangkaian Pengirim Sinyal (TX)

\begin{tabular}{|c|l|c|c|}
\hline No & \multicolumn{1}{|c|}{ Komponen } & Vin & \multirow{2}{*}{ Kondisi } \\
\hline 1 & Kunci kontak on & 11,78 Volt & \multirow{2}{*}{} \\
\hline 2 & Relay 1 & 12,8 Volt & \\
\hline
\end{tabular}

\section{Analisa}

Keterangan :

$\mathrm{Vcc}=12,8 \mathrm{~V}$

$\mathrm{Rc}=775 \Omega: 1000=0,775 \mathrm{~K} \Omega$ 
Dimana nilai Vec dan Re merupakan nilai hasil pengukuran, sehingga nilai Ic dapat dicari dengan menggunakan persamaan (2.3) :

$$
\begin{aligned}
I c & =\frac{V c c-V c e}{R c} \\
& =\frac{12,8-0}{775 \Omega} \\
& =0,016 \times 100 \\
& =1,6 \mathrm{~mA}
\end{aligned}
$$

Jadi diketahui Ic $=1,6 \mathrm{~mA}$

$\mathrm{Vce}=\mathrm{Vcc}-\mathrm{Ic} . \mathrm{Rc}$

$\mathrm{Vce}=12,8 \mathrm{~V}-(1,6 \mathrm{~mA})(0,775 \mathrm{~K} \Omega)$

$\mathrm{Vce}=12,8-1,24$

Vce $=11,56$ Volt

Pada pengukuran rangkaian pengirim sinyal (Tx), tegangan Vin 12,8 Volt dari kelistrikan mesin yang melewati transistor, basis pada transistor 11,56 Volt merupakan pemicu bagi relay 1 maka kontaktor relay 1 yang akan mengontakkan tombol keypad pada handphone. Dari hasil pengukuran tidak terlalu jauh selisih dengan perhitungan, dimana pada hasil pengukuran adalah sebesar $11,78 \mathrm{~V}$ dan hasil perhitungan sebesar 11,56 V. Dari hasil pengukuran dengan hasil perhitungan terdapat selisih sebesar 0,22 Volt.

\section{KESIMPULAN}

Berdasarkan pada hasil pengujian dan analisa sistem pengamatan sepeda motor menggunakan telepon seluler(handphone), maka dapat diambil beberapa kesimpulan sebagai berikut :

1. Sitem akan memanggil (menelpon) pemilik sepeda motor apabila sepeda motor di hidupkan secara paksa.

2. Sistem akan mematikan mesin sepeda motor dan menghidupkan alarm jika handphone sistem mendapat panggilan dari handphone pemilik kendaraan.

3. Sepeda motor yang telah mati secara otomatis tidak dapat dihidupkan dengan kunci kontak sebelum menekan tombol reset pada modul.

4. Sistem alarm akan bekerja selama pulsa pada handphone kendaraan mencukupi untuk melakukan panggilan ke handphone pemilik kendaraan.

5. Selain pulsa hal yang terpenting adalah handphone pada kendaraan ada tegangan sehingga dapat melakukan panggilan ke handphone pemilik kendaraan.

\section{REFERENSI}

[1] Malvino,Albert Paul. 1992. Prinsip-prinsip Elektronika. Alih bahasa : M. Barmawi,Jakarta:Erlangga

[2] Gouzali Saydam, Drs. Bc. TT. 1997. Teknologi Telekomunikasi. Bandung:Angkasa.

[3] Bishop, Owen 2004. Dasar-dasar Elekronika.Jakarta.Erlangga.

[4] Scitomer, a. 1992a. Elektronika Untuk Pemula. Alih bahasa : Y. Budi Susanto. Jakarta: Elex Media Komputindo.
[5] Richard Blocher, Dipl Phys. 2003. DasarElektronika. Yogyakarta Andi Yokyakarta,

[6] Kho, Dickson. 2014. Pengertian

LED.http://teknikelektronika.com/pengertian-1-light-emittingdiode/

(1 September 2016)

[7] Tio. 2014. Pengertian Sensor Cahaya dan Sensor Air. http://komponenelektronika.biz/sensorcahaya.html

[8] http://elektronika-dasar.web.id/transistor-sebagai-saklar/ diakses pada

tanggal 11 Nopember 2016

[9] http://kafkapa.blogspot.com/2012/03/rangkaian-transistordarlington.html

[10] www.baterai_motor.co.id 